
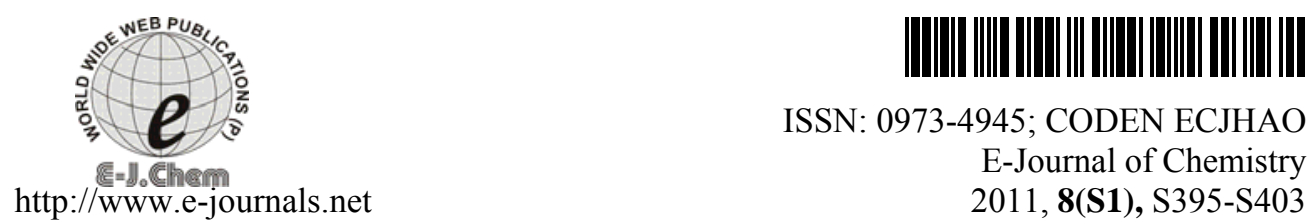

ISSN: 0973-4945; CODEN ECJHAO

E-Journal of Chemistry

2011, 8(S1), S395-S403

\title{
X-Ray Diffraction and SEM \\ Investigation of Solidification/ Stabilization of Nickel and Chromium Using Fly ash
}

\author{
RANJANA A. PATIL ${ }^{*}$ and SANGESH P. ZODAPE \\ *Yeshwantrao Chavan College of Engineering, Hingna Road \\ Wanadongari, Nagpur-441 110, Maharashtra, India \\ N. Y. S. S. College of Engineering and Research \\ Hingna Road, Wanadongari, Nagpur-441 110, Maharashtra, India \\ ranpati@rediffmail.com \\ Received 8 February 2011; Revised 15 May 2011; Accepted 5 June 2011

\begin{abstract}
The main thrust of the paper is mechanism of immobilization of nickel(Ni) and chromium(Cr) metal sludge by solidification/stabilization using lime fly ash and sand (LFAS). The mineralogy of fly ash used for the study has been determined on the basis of $\mathrm{x}$ - ray diffraction analysis (XRD). Attempts have been made to investigate the consequences of interaction of heavy metal ion with constituents of lime fly ash sand composite on the basis of XRD studies and scanning electron microscopy (SEM, except chromium).
\end{abstract}

Keywords: LFAS, XRD, Sludge, SEM

\section{Introduction}

Solidification/ stabilization of toxic materials by the formation of a cementitious solid is a common and economical method for the treatment of hazardous chemical waste prior the ultimate disposal ${ }^{1}$. The cementitious binders used were either ordinary portland cement or the fly-ash. The solidified/ stabilized waste can be safely disposed in landfills so that contamination of soil or ground water is minimized. The mechanisms by which the waste is stabilized was generalized by several earlier workers ${ }^{2-7}$. The present paper deals with the mechanism of immobilization of nickel sludge using x-ray diffraction study and scanning electron microscopy.

\section{Experimental}

Fly ash was collected from "Koradi" thermal power plant near Nagpur (India) and the waste containing nickel and chromium received from electroplating and tannery industries. The lime and standard Ennore sand was procured from local market. 


\section{Procedure}

\section{Preparation of LFAS cubes and leaching test}

Appropriate proportions of lime fly ash and sand were mixed with suitable quantity of water. The freshly mixed paste was then poured in to $5 \mathrm{~cm}^{3}$ moulds. Casting had been done by applying a load of $100 \mathrm{Kg} / \mathrm{cm}^{2}$, the cubes were cured at an optimum pressure of $0.351 \mathrm{~kg} / \mathrm{cm}^{2}$ for $2.5 \mathrm{~h}$. The representative sample was collected from one of the LFAS cubes after crushing and sieving. The sample was subjected to XRD analysis. The waste water from electroplating Industry containing nickel was mixed with selected proportion of lime- fly sand admixtures. The cubes were cast out of this admixture and steam cured as per the procedure described.

During the second set of experiment the tannery waste containing chromium was mixed with suitable quantity of fly ash lime sand and water. Same procedure was applied for casting the cubes as mentioned above. The cubes containing nickel waste and chromium waste were crushed, powdered and a representative samples were collected and subjected to $\mathrm{x}$ - ray diffraction analysis. The another set of cubes containing known quantity of nickel sludge and chromium sludge cubes were subjected to leaching test as per minnesota pollution control agency using sodium acetate acetic acid buffer solution ${ }^{8}$. The cubes were placed in a container containing acid buffered leaching solution maintaining solid to liquid ratio as 1:4. The container was shaken vigorously for one minute and was kept undisturbed. After the definite time interval $\mathrm{pH}$ of leaching medium was adjusted to 4.9 to 5.2 and volume of solution was maintained constant by adding requisite quantity of solution. Then $50 \mathrm{~mL}$ of leachate was withdrawn and was filtered through whatmans filter paper and $\mathrm{pH}$ of this solution was adjusted to 2 by adding nitric acid. Atomic absorption analysis for metal ion in solution was carried out on atomic absorption spectrophotometer (Model Z 8000 with arrangement of data processor).

\section{$X$ ray diffraction study}

X-ray diffraction study was carried out in Indian Bureau of Mines, Nagpur. The sample was powdered to 325 mesh size. The powdered sample was passed through mixture mill to make it homogenous for x-ray diffraction studies. X- ray diffraction study was carried out on Philps PW 1710 powder diffractometer. The sample was analysed under the x-ray of wave length 1.54180 produced by using copper target during the course of studies. Nickel filter was introduced in the way of X-ray beam produced to allow only $\mathrm{Cu} \mathrm{K} \alpha$. X-ray pass through the sample. During the course of $x$-ray scanning of samples the voltage used to generate $\mathrm{x}$-ray was $35 \mathrm{Kv}$ and current was $25 \mathrm{~mA}$. The scanning speed was $10200 / \mathrm{min}$. $\mathrm{X}$ - ray diffraction patterns were obtained, exhibiting the characteristic peaks along with the $\mathrm{d}$ values in angstron units and the corresponding peak intensities of the mineral phases present in the sample.

\section{Scanning electron microscopy}

The studies on morphology of unleached and leached fronts of LFAS composite containing nickel sludge was carried out by scanning electron microscopy. The electron microphotographs were recorded on a steroscan 250 MKS, Cambridge (U.K.) electron microscope at RSIC Nagpur. This is a high resolution scanning electron microscope designed to operate easily with guaranteed resolution as high as $60 \AA$ and $45 \AA$ attainable. The range of magnification is $20 \times 800,000$ at $10 \mathrm{~mm}$. 


\section{Results and Discussion}

\section{$X$-ray diffraction [XRD] studies on mineralogy of fly-ash}

When the term mineralogy was applied to plant, it found that ashes typically refers to chemical inorganic compounds both crystalline and non crystalline. These are constituents that react and control the initial behavior of ash when in contact with the solution required for ash utilization and disposal.

During combustion the mineral inclusions in coal decompose and fuse. Most of the mineral matters adhere to the surface of the charred particles ${ }^{9}$. As the char surface recedes, the ash inclusions are drawn together and coalesce to form larger ash particles, the size and composition of which were determined by the type of ash, inclusions in the original particular fragment. The resultant fly ash size and composition was therefore determined by the fragmentation pattern of $\operatorname{ash}^{10}$.

The fly ash used in the present work has been studied by x-ray powder diffraction technique using $\mathrm{Cu} \mathrm{k} \alpha$ radiation. This was done in order to determine various mineral and inorganic phases present in the fly ash. The x-ray diffractogram of Fly ash is shown in Figure 1. The main components present in fly ash were found to be $-[\alpha-$ Quartz $[\approx 60 \%]$ followed by sillimanite $20 \%$ hematite [ $13 \%$ ] with traces of corundum. Besides these the fly ash also contain trace amount of meghamite $\left[(\gamma) \mathrm{Fe}_{2} \mathrm{O}_{3}\right]$ ultra traces of magnetite, fylite, pyrrholite and mullite etc. Theses phases are only observed when heavy media separation of fly-ash had been done with bromoform $[\mathrm{Sp}$. gr. $=2.88]$ and subsequently subjected to isodynamic separation. The light residue, heavy residue obtained by gravitational and magnetic separation are analysed and their $\mathrm{x}$ - ray diffractograms are displayed in Figure 2 and Figure 3 respectively. The main phases obtained in fly ash before and after separation are shown in Table 1.

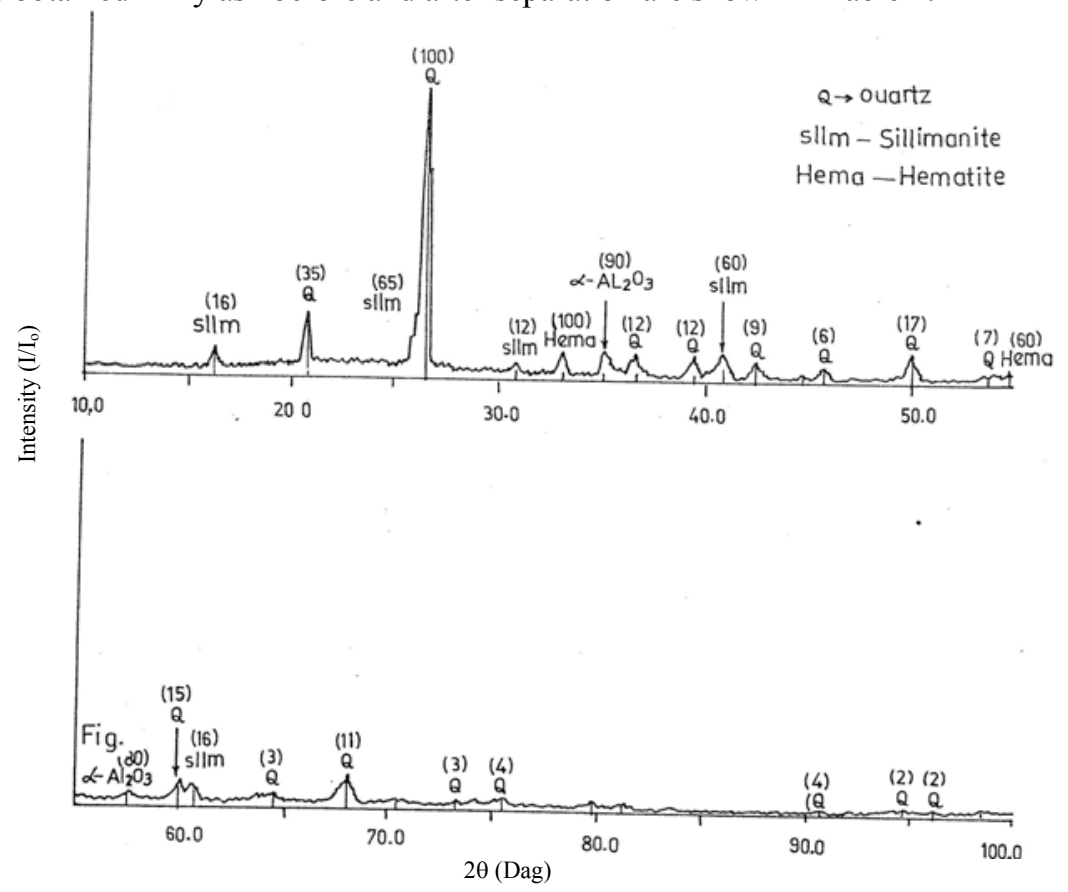

Figure 1. X-ray diffraction of fly ash (direct) 


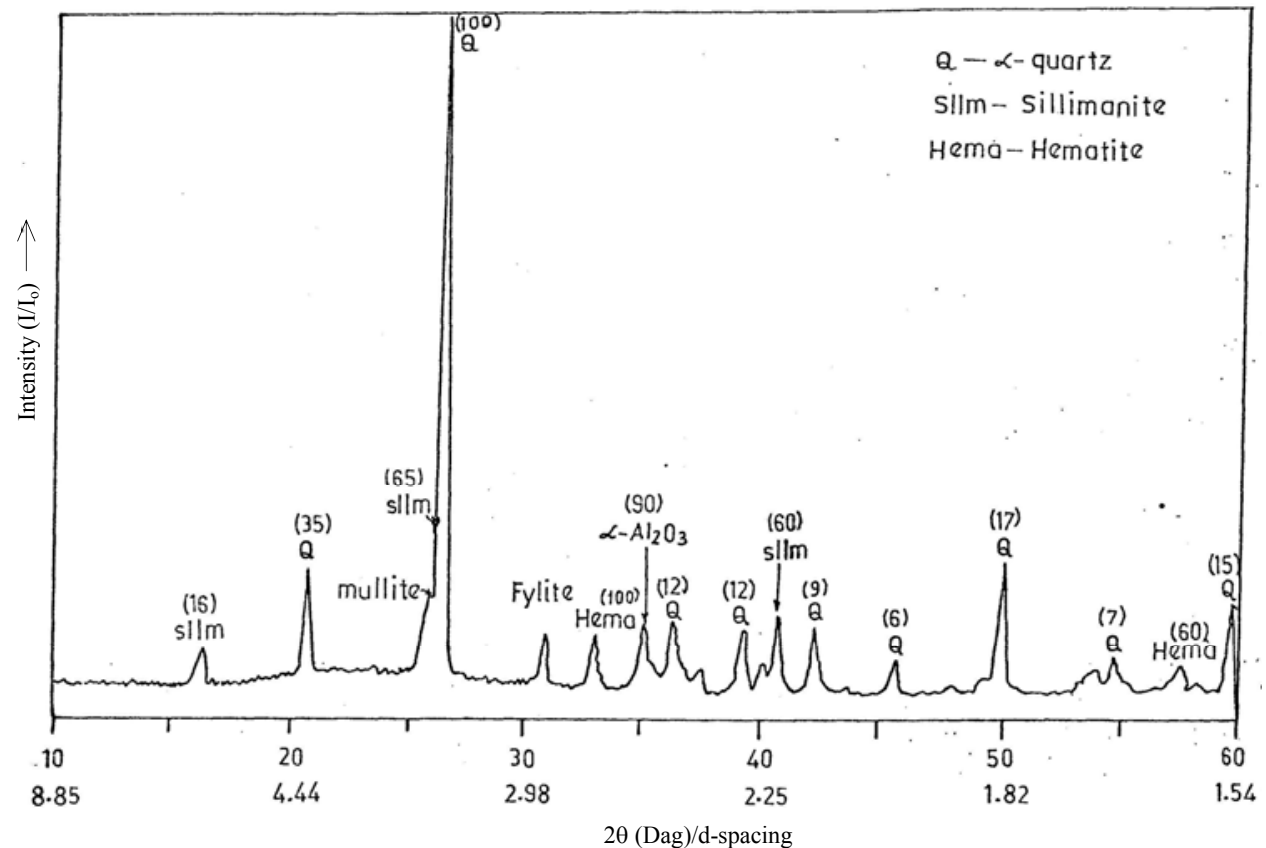

Figure 2. X-Ray diffractogram of lighter residue (Bromoform separation)

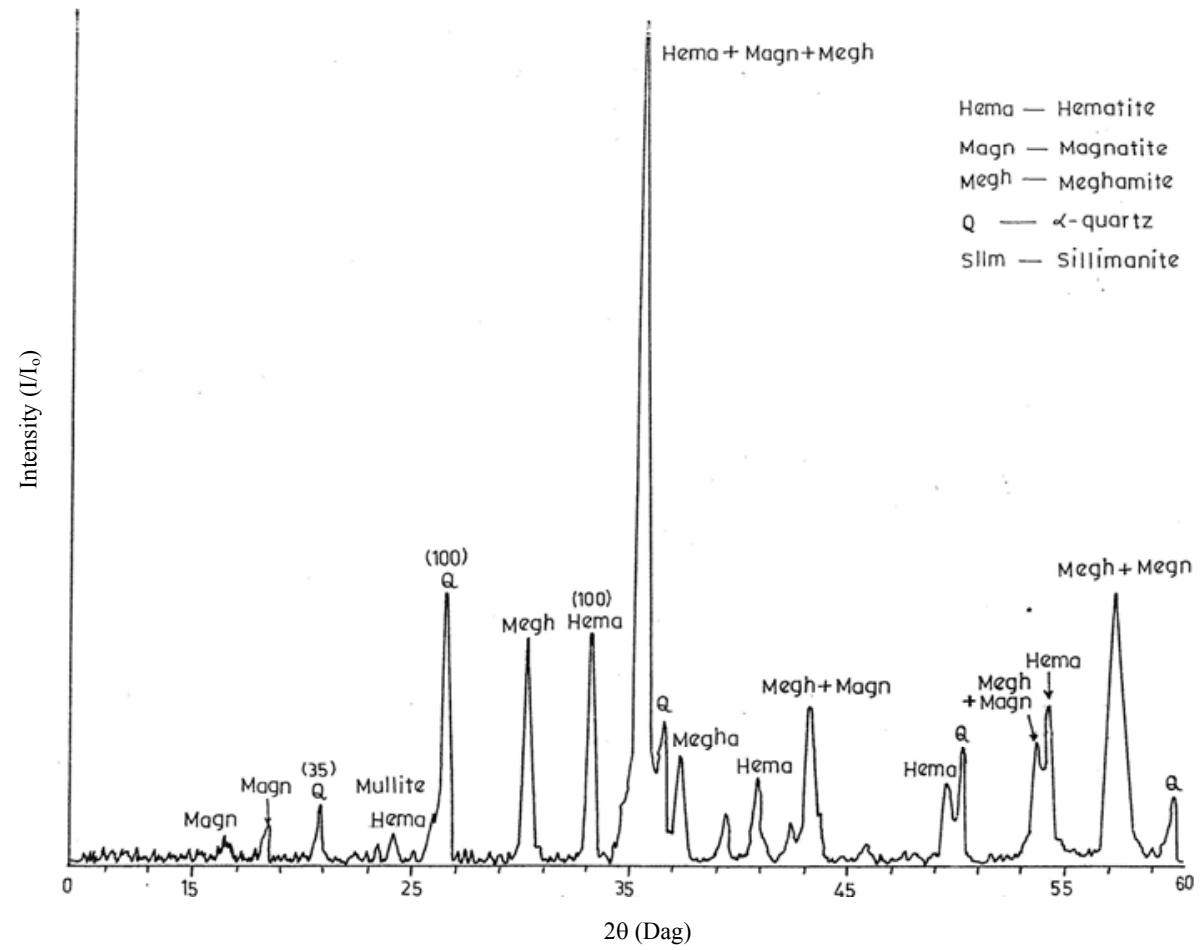

Figure 3. X-Ray diffractogram of heavy portion (Magnetic) (Bromoform separated) 
Table 1. Minerals found in fly ash before and after gravitational separation and their characteristics d value $(\AA)$

\begin{tabular}{|c|c|c|c|c|c|}
\hline Mineral & & & & & \\
\hline Quartz(Q) & $\mathrm{SiO}_{2}$ & $\begin{array}{c}\mathrm{Q} \\
(68 \%)\end{array}$ & $\begin{array}{c}\mathrm{Q} \\
(60 \%)\end{array}$ & $\begin{array}{c}\mathrm{Q} \\
(12 \%)\end{array}$ & $\begin{array}{c}4.26(35), 3.34(100), \\
1.82(17)\end{array}$ \\
\hline $\begin{array}{l}\text { Sillimanite } \\
\quad \text { (Sllm) }\end{array}$ & $\mathrm{Al}_{2} \mathrm{SiO}_{5}$ & $\begin{array}{l}\text { Sllm } \\
(21 \%)\end{array}$ & $\begin{array}{c}\text { Sllm } \\
(18 \%)\end{array}$ & --- & $\begin{array}{c}3.42(100), 3.37(65) \\
2.204(60)\end{array}$ \\
\hline Corundum & $\mathrm{Al}_{2} \mathrm{O}_{3}$ & $\begin{array}{l}\text { Corundum } \\
\text { (traces) }\end{array}$ & $\begin{array}{l}\text { Corundum } \\
\text { (traces) }\end{array}$ & --- & $\begin{array}{c}3.479(75), 2.552(95), \\
2.085(100)\end{array}$ \\
\hline $\begin{array}{l}\text { Hamatite } \\
\text { (Hema) }\end{array}$ & $\mathrm{Fe}_{2} \mathrm{O}_{3}$ & $\begin{array}{l}\text { Hema } \\
(13 \%)\end{array}$ & $\begin{array}{l}\text { Hema } \\
(10 \%)\end{array}$ & $\begin{array}{l}\text { Hema } \\
(18 \%)\end{array}$ & $\begin{array}{c}2.69(100), 1.69(60), \\
2.51(50)\end{array}$ \\
\hline $\begin{array}{l}\text { Magnetite } \\
\text { (Magn) }\end{array}$ & $\mathrm{Fe}_{3} \mathrm{O}_{4}$ & --- & --- & $\begin{array}{l}\text { Magn } \\
(10 \%)\end{array}$ & $\begin{array}{c}2.532(100), 1.61(30), \\
1.4844(80)\end{array}$ \\
\hline $\begin{array}{l}\text { Meghamite } \\
\text { (Megh) }\end{array}$ & $\mathrm{Fe}_{2} \mathrm{O}_{3}$ & --- & --- & $\operatorname{Megh}(55 \%)$ & \\
\hline Mullite & $\begin{array}{c}3 \mathrm{Al}_{2} \mathrm{O}_{3} .2 \\
\mathrm{SiO}_{2}\end{array}$ & $\begin{array}{l}\text { Mullite } \\
\text { (traces) }\end{array}$ & $\begin{array}{l}\text { Mullite } \\
\text { (traces) }\end{array}$ & $\begin{array}{l}\text { Mullite } \\
\text { (traces) }\end{array}$ & $\begin{array}{c}3.48(95), 3.39(100) \\
2.206(60)\end{array}$ \\
\hline Fylite & & --- & $\begin{array}{l}\text { Fylite } \\
\text { (traces) }\end{array}$ & --- & 2.8 \\
\hline Pyrrhotite & $\mathrm{FeS}$ & --- & --- & $\begin{array}{l}\text { Pyrrhotite } \\
\text { (Traces) }\end{array}$ & 2.06 \\
\hline
\end{tabular}

The mineralogy of Indian fly ash has been extensively studied by Tripathy et al ${ }^{11}$. Few minerals which were reported in earlier work are not observed in the present case. This may be attributed to the different petrogenesis of coals, coal seam and type of coal used in thermal power plant. Various mineral inorganic phases detected in ash were mostly different from those which occur and found in coal. Alpha-quartz in plant probably originated from quartz inclusion in the feed coal, which was not fully melted during combustion. Weast ${ }^{12}$ 1974 stated that all particles were not exposed to temperature above $1710^{\circ} \mathrm{C}$ i.e. the melting point of quartz. Recrystallization of quartz was most unlikely due to rapid cooling of ash particles. The clay minerals present in coal undergo decomposition during combustion ${ }^{13}$.

$$
\mathrm{Al}_{2} \mathrm{Si}_{2} \mathrm{O}_{5}(\mathrm{OH})_{4}=\mathrm{Al}_{2} \mathrm{O}_{3} .2 \mathrm{SiO}_{2}+2 \mathrm{H}_{2} \mathrm{O} \rightarrow \mathrm{Al}_{2} \mathrm{SiO}_{5}+2 \mathrm{SiO}_{2}
$$

In view of above decomposition the quartz present would have been due to the subsequent decomposition of mullite/ sillimanite. The iron oxide which was present in coal was basically due to decomposition / oxidation of pyrites. So it appears in the fly ash as hematite and pyrollite. The iron oxide $\left((\alpha)=\mathrm{Fe}_{2} \mathrm{O}_{3}\right)$ when heated gives magnetite $\left((\gamma) \mathrm{Fe}_{3} \mathrm{O}_{4}\right)$. The presence of $(\gamma) \mathrm{Fe}_{2} \mathrm{O}_{3}$ is confirmed by XRD and same as shown in Figure 3. The study of mineral phases present in coal ash was done with a view to ascertain the changes that occurred in the mineralogical phases in hydrated product of lime fly ash sand composites. Fly ash when mixed with lime in presence of water and cured leads to the formation of calcium silicate hydrate which was a cementitious product.

$$
\begin{gathered}
\mathrm{SiO}_{2}+\mathrm{Ca}(\mathrm{OH})_{2}+(\mathrm{n}-1) \mathrm{H}_{2} \mathrm{O} \rightarrow \mathrm{CaO} . \mathrm{SiO}_{2} \mathrm{nH}_{2} \mathrm{O} \\
\text { (Calcium silicate hydrate) }
\end{gathered}
$$

The silica in amorphous form is known to react lime readily as compared to silica in crystalline form. In fact this constitutes a different form of Fly ash and other pozzolanic materials. Although it is generally believed that lime silica reaction is the main or only reaction of interest, recent information indicates that alumina or iron also takes part in the chemical reactions which are very complex. Pozzolana concrete is usually set by reaction such as 
$2\left(\mathrm{Al}_{2} \mathrm{O}_{3} .2 \mathrm{SiO}_{2}\right)+7 \mathrm{Ca}(\mathrm{OH})_{2}+$ Water $\rightarrow 3 \mathrm{CaO} .2 \mathrm{SiO}_{2}$ aqua $+2\left(2 \mathrm{CaO} . \mathrm{Al}_{2} \mathrm{O}_{3} \cdot \mathrm{SiO}_{2}\right)$ aqua

The final strength of pozzolanic concrete varies with the amount of lime present. For most pozzolanas the optimum percentage of lime for maximum compressive strength is around $25-28 \%$ although this varies with composition of pozzolana itself. The compressive strength of pozzolana concrete is not particularly high, seldom exceeds about $15 \mathrm{MN} / \mathrm{M}^{2}$, even several years later on. The main advantage of pozzolana cement concrete over other forms are excellent resistant to sea water and many other solutions, particularly sulphate and their relative cheapness.

$X$-Ray diffraction study on lime fly ash sand (LFAS) composite containing nickel and chromium sludge

$\mathrm{X}$-ray diffraction study was carried out by using nickel waste from electroplating industry in LFAS composite. X-Ray diffractogram of lime Fly sand [LFAS] composite material obtained after steam curing at $0.35 / \mathrm{Kg} \mathrm{cm}$ for $3 \mathrm{~h}$ which is represented in Figure 4 where XRD pattern clearly reveals the existence of calcite, sillimanite, Quartz, corundum etc and also the formation of calcium, silicate hydrate $[\mathrm{C}-\mathrm{S}-\mathrm{H}]$. Calcium silicate hydrate is the main cementitous product in LFAS composite which contributes towards strength. The XRD pattern shown in Figure 5 and 6 shows that the formation of C-S-H is not evident. This shows that the presence of nickel have hindered the formation of $\mathrm{C}-\mathrm{S}-\mathrm{H}$ which is the main cementitous product formed during lime fly ash reaction. Thus there will be reduction in strength of LFAS composite in presence of nickel ion. Such observation was also been reported by N. L. Thomas $^{14}$ in his studies with Portland cement. Surprisingly the presence of calcium silicate Hydrate was clearly visible in case of lime fly ash sand composite containing chromium in the XRD pattern shown in Figure 7. This also accounts for greater physical integrity of the LFAS cubes containing $\mathrm{Cr}(\mathrm{OH})_{3}$. Further the amount of leached $\mathrm{Cr}^{3+}$ leached out from LFAS composite in to the leaching medium was quite less as compared to Nickel as evident from Table 2. Thus it was clear that formation of C-S-H not only contributes towards the physical integrity of LFAS cubes but also in improving the immobilization of heavy metal.

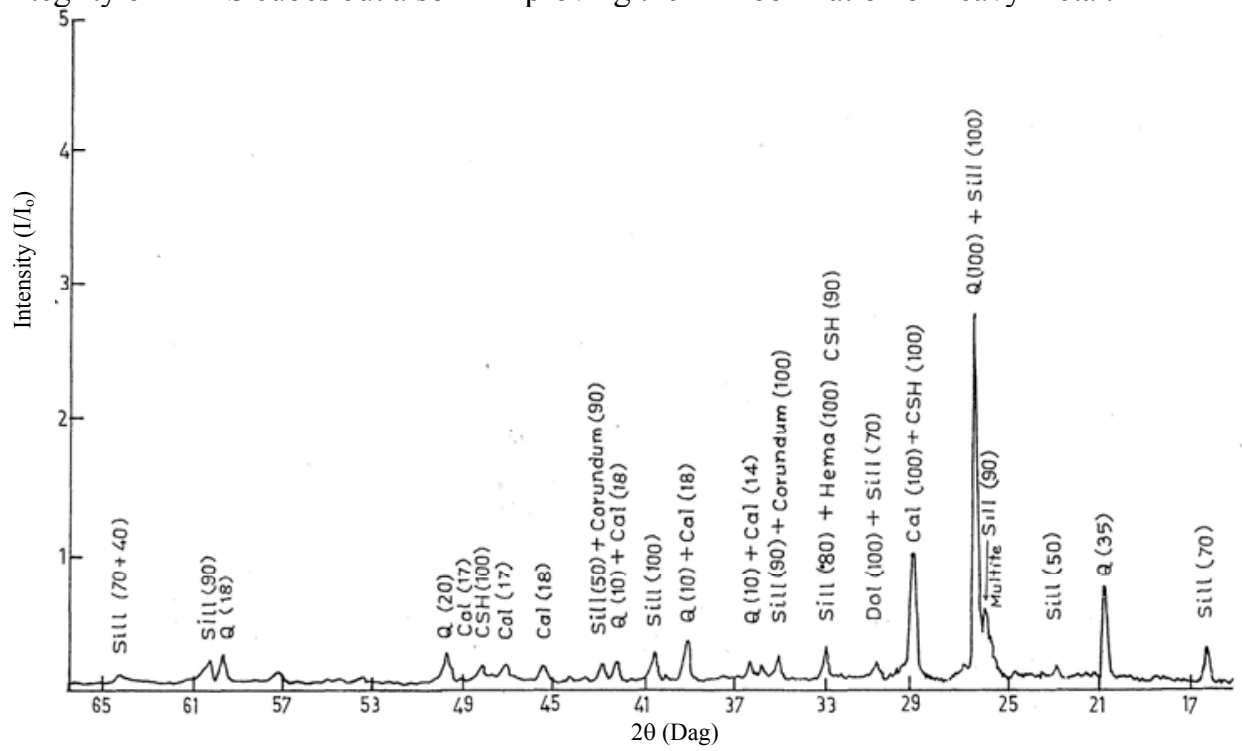

Figure 4. XRD pattern of simple lime fly ash sand (LFAS) composites 


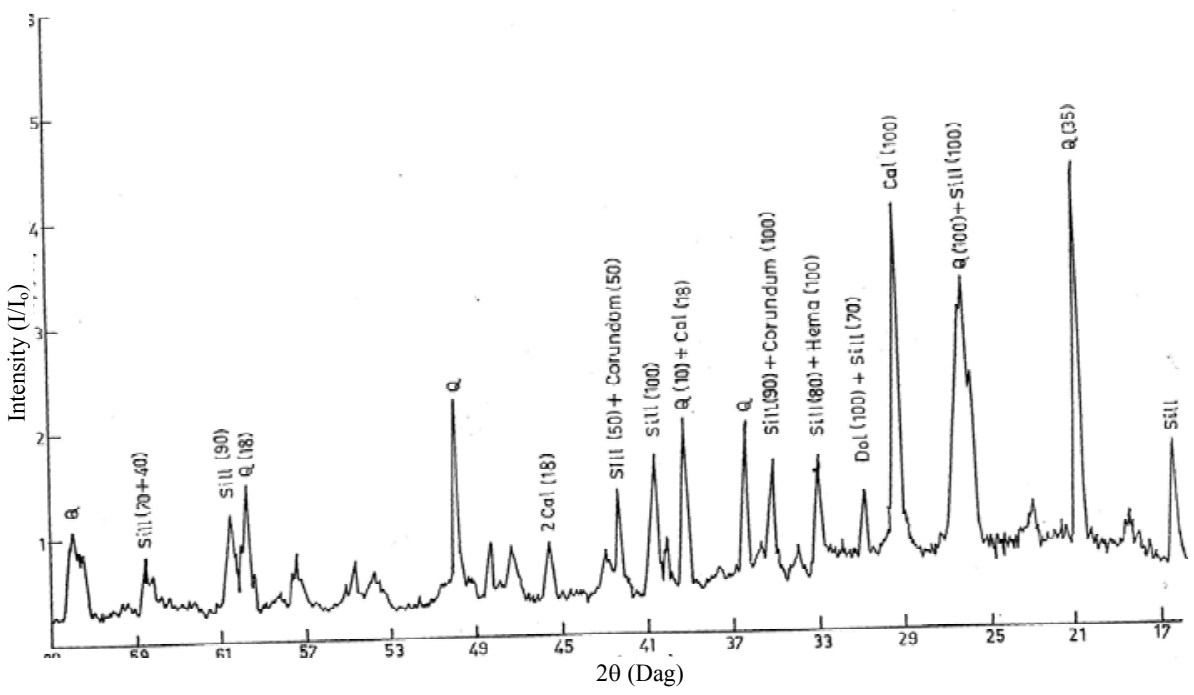

Figure 5. XRD pattern of steam cured LFAS Cube containing nickel hydroxide sludge

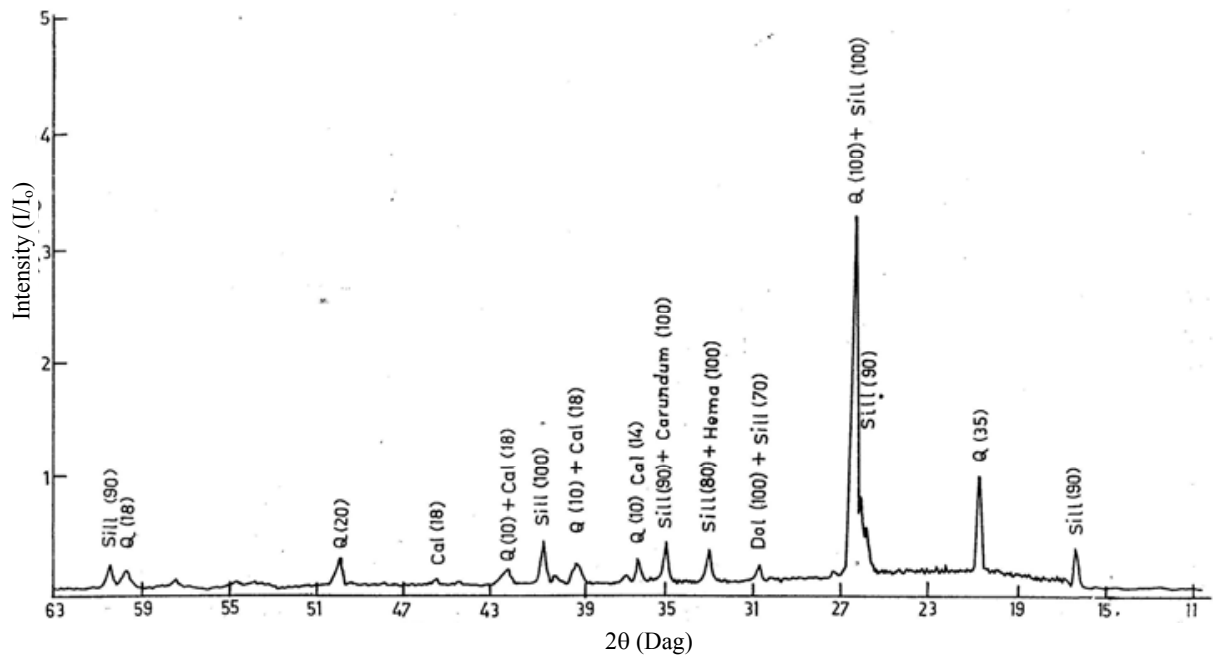

Figure 6. XRD pattern of steam-cured LFAS cube containing nickel hydroxide sludge after leaching with acetic acid- sodium acetate buffer

Table 2. Percentage of nickel and chromium leached from LFAS composite in to the leaching medium at different contact time. Composition of admixture: $-65 \%$ fly ash $+25 \%$ lime $+10 \%$ Sand

\begin{tabular}{ccc}
\hline $\begin{array}{c}\text { Contact } \\
\text { Period(in Days) }\end{array}$ & $\begin{array}{c}\text { \% of Nickel } \\
\text { leached }\end{array}$ & $\begin{array}{c}\text { \% of Chromium } \\
\text { leached }\end{array}$ \\
\hline 5 & 0.536 & 0.52 \\
10 & 1.69 & 0.55 \\
15 & 2.25 & 0.74 \\
20 & 3.35 & 0.85 \\
25 & 3.90 & 1.07 \\
\hline
\end{tabular}




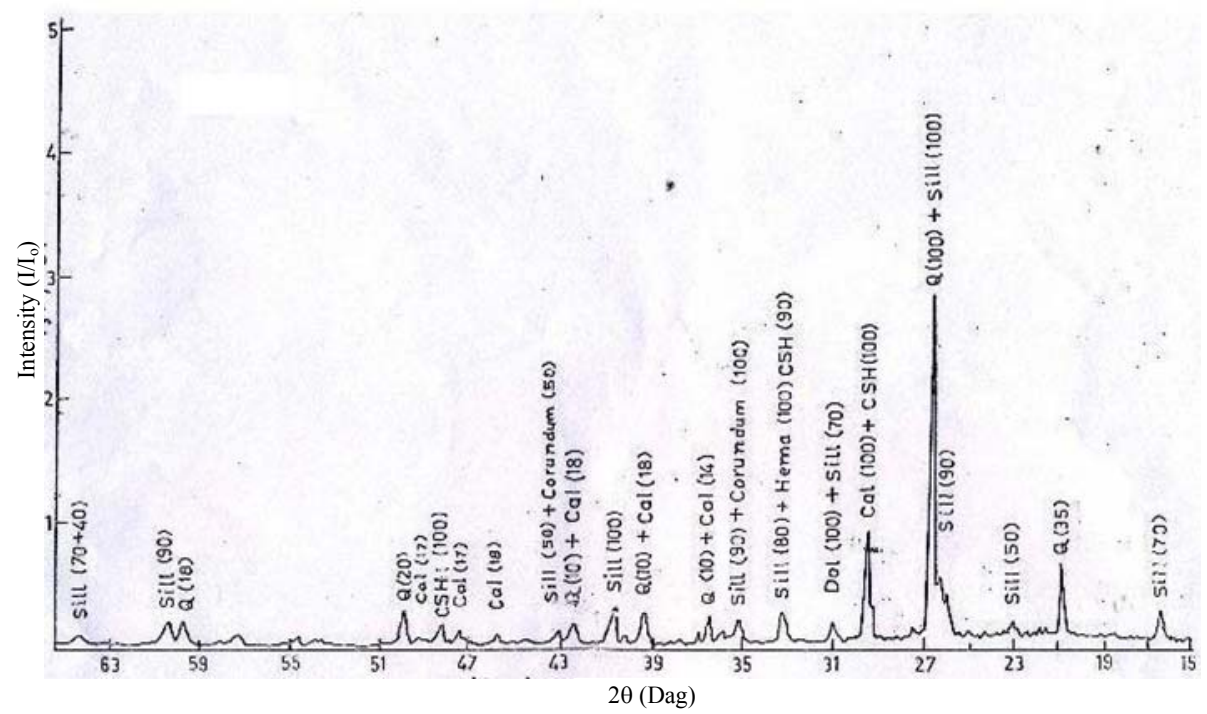

Figure 7. XRD pattern of steam-cured LFAS cube containing $\mathrm{Cr}(\mathrm{OH})_{3}$ sludge

\section{Scanning electron microscopy on LFAS composite containing nickel sludge}

The morphology of LFAS composite containing $\mathrm{Ni}(\mathrm{OH})_{2}$ sludge can be seen from scanning electron micrograph shown in Figure 8. Figure 9 shows the SEM of LFAS composite containing $\mathrm{Ni}(\mathrm{OH})_{2}$ sludge after leaching test which is conducted as per M.P.C.A ${ }^{8}$ procedure. It can be seen from Figure 8 that unleached sample possess rather uniform and compact structure whereas leached sample showed small cavities and cracks. This also explains the slight reduction of compressive strength of LFAS cubes after prolonged leaching with sodium acetate and acetic acid.

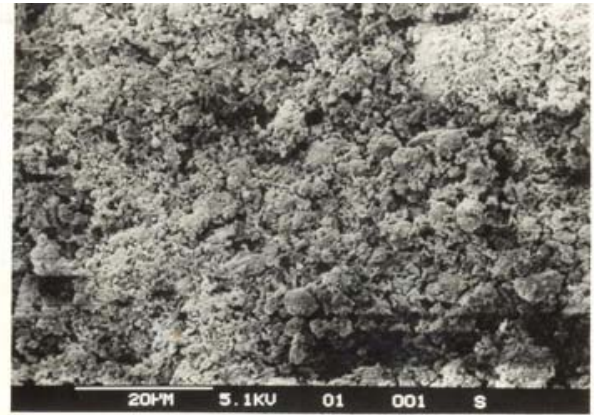

Figure 8. SEM Micrograph of unleached LFAS composite containing nickel hydroxide sludge

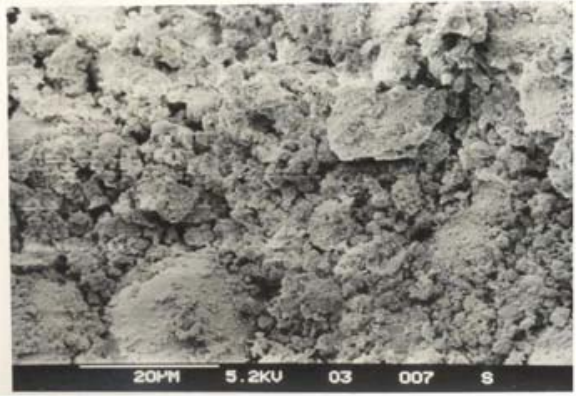

Figure 9. SEM micrograph of leached LFAS composite containing nickel hydroxide sludge

The scanning electron micrograph of LFAS composite containing $20 \%$ cement and nickel hydroxide sludge is shown in Figure 10. It can be seen from the figure that, attack of LFAS composite with leaching medium is more severe in this case probably because of increased porosity of cement. This explains why simple lime-fly ash sand admixtures gave better immbolization of heavy metal as compared to solidification / stabilization in ordinary portland cement. 


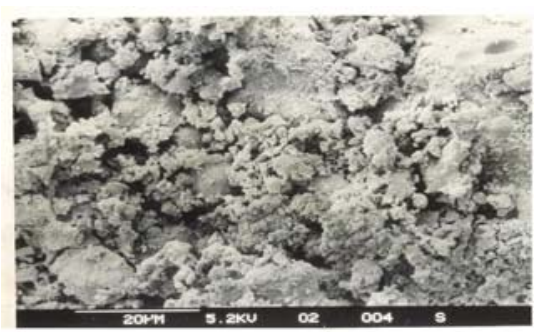

Figure 10. SEM micrograph of leached LFAS composite containing $20 \%$ cement and nickel hydroxide

\section{Conclusion}

The major mechanism of solidification / stabilization process for electroplating waste containing nickel and tannery waste containing chromium using fly ash seem to be adsorption and pozzolanic encapsulation. The strength of LFAS composite cube is contributed mostly by C-S-H and calcite. Metal ion like nickel is found to be inhibiting the formation of calcium silicate hydrate which is an important cementitous material that contributed towards the strength and physical integrity. However, it is interesting to note that $\mathrm{Cr}^{+3}$ ions are not inhibiting the formation of C-S-H (calcium silicate hydrate). This accounts for the fact that LFAS composite involving tannery waste containing $\mathrm{Cr}^{+}$exhibits a better physical integrity and also the immoblization of metal ion achieved in this case is more efficient than that of nickel ion present in electroplating waste.

\section{Acknowledgment}

We are thankful to Indian Bureau of Mines and SAIF, Rashtrasant Tukadoji Maharaj Nagpur University, Nagpur for providing research facilities. We are also grateful to the reviewers for their valuable comments and suggestions.

\section{References}

1. Conner J R, Chemical Fixation and Solidification of Hazardous wastes, Van Nastrand Reinhold, New York, HY, 1990, 692.

2. Cinquapalmi M A, Mangialandi T, Pani L, Paolini A E and Pigal L, J Hazard Mater., 2008, 511(2-3), 585-593.

3. Sophia C and Swaminathan K, Chemosphere, 2005, 58, 75-82.

4. $\quad$ Singh T S, J Hazard Mater., 2006, 131, 29.

5. Bulewicz E M, Kozak A and Kowaski Z, Ind Eng Chem Res., 1997, 36(10), 4381.

6. Giergiczny Z and Krol A, J Hazard Mater., 2008, 160(2-3), 247-255.

7. Wenshi L, Haobo Hou and Chuhao Zang D Z, Waste Manage Res., 2009, 27, 258-266.

8. Minnesota Polution control agency, land Disposal Leach Test circa, 1978.

9. Raask E, J Inst Fuel, 1968, 44, 339-344

10. Sarofim A F, Howard J B and Padia A S, Combust Sci Technol, 1977, 16, 187-204.

11. Tripathy S, Powell M A, Hart B R, Sahu K C and FyFe W S, Mineralogy of Indian Flyash Proc Int Conf on Environmental Impact of coal utilization from raw material to waste resources, 1991, 185-192.

12. Weast R C, Hand Book of Chemistry and Physics, CRC Press, Cleveland, Ohio, $\mathrm{Pb} 133$ and B154, 1975.

13. Padia A S, Sarofim A F, Howard J B and Kobayashi H, Combust Inst Cen States Sect. Spring MB07 Lisbon - Sustainable Construction, Materials and Practices: Challenge of the Industry for the New Millenium, 1976.

14. Thomas N L, Jameson D A and Double D D, Cem Concr Res., 1981, 11, 143-153. 


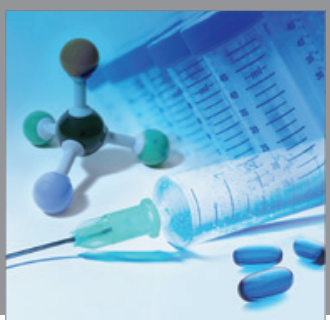

International Journal of

Medicinal Chemistry

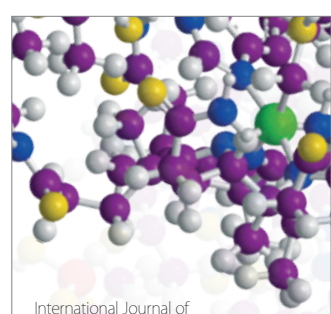

Carbohydrate Chemistry

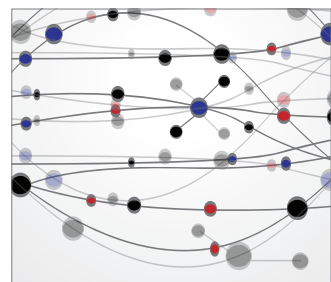

The Scientific World Journal
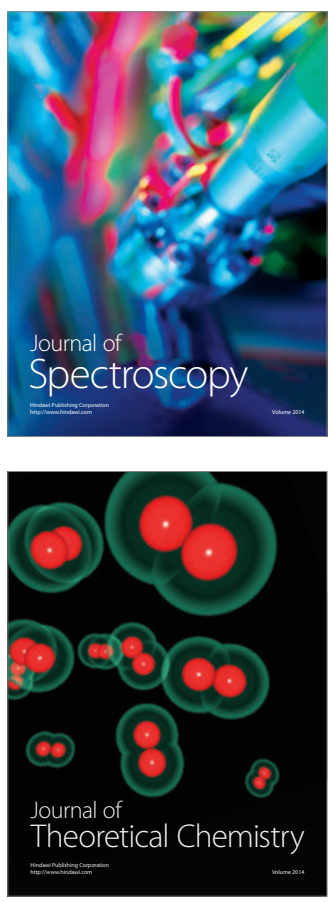
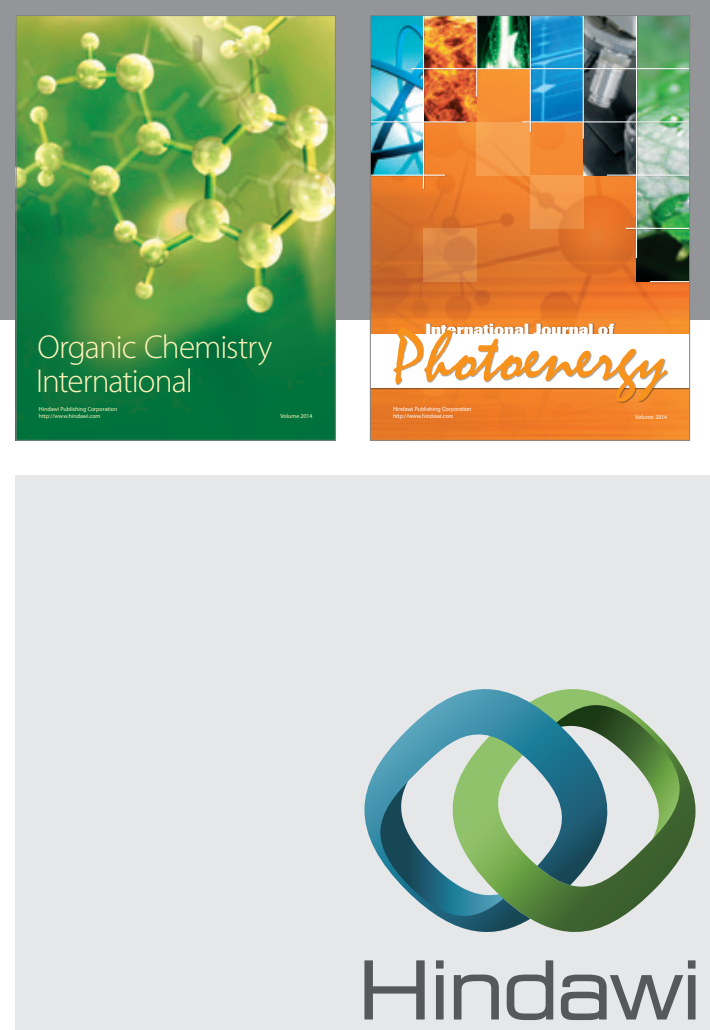

Submit your manuscripts at

http://www.hindawi.com
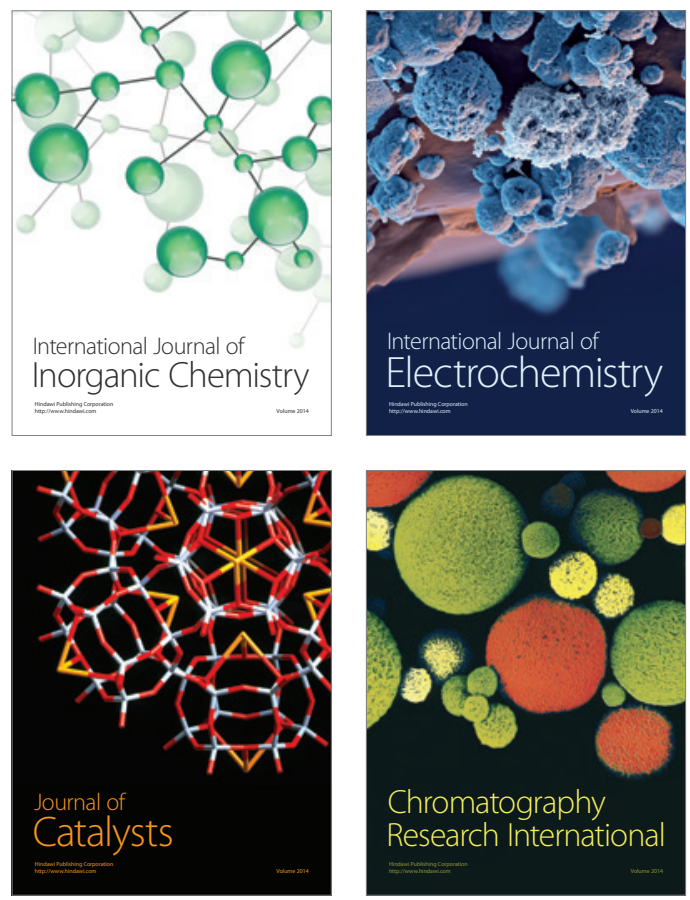
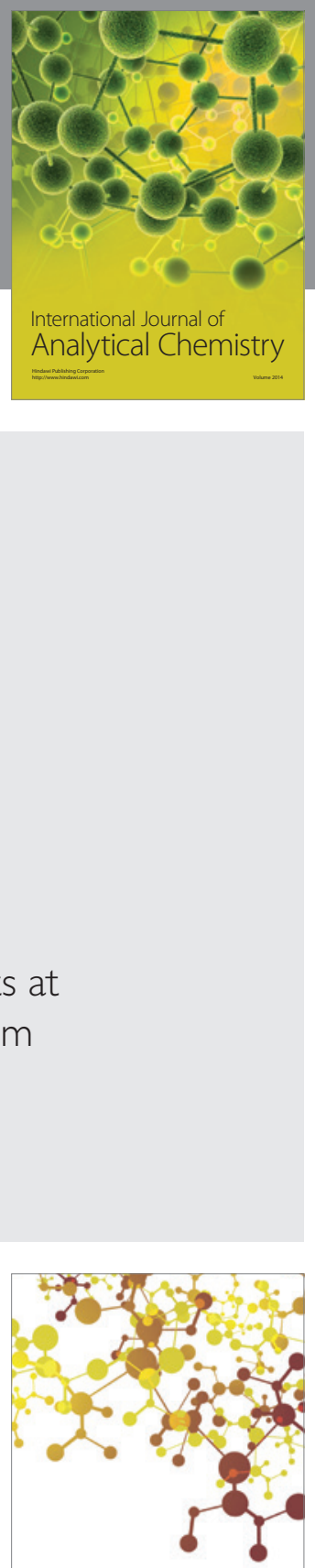

Journal of

Applied Chemistry
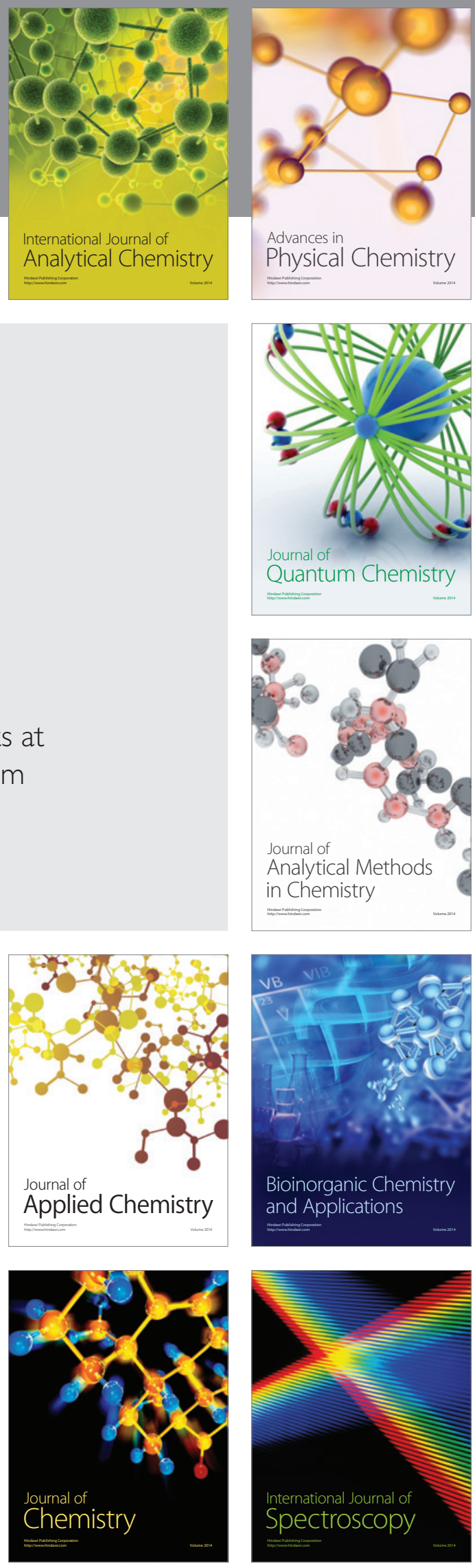